I.М. Трофимов, В.Ф. Зюкін, І.В. Гурєєв, І.О. Гурін, О.М. Дзігора

Харківський національний університет Повітряних Сил ім. І. Кожедуба, Харків

\title{
ЗАХИСТ РЛС ВІД ВИСОКОТОЧНОї ЗБРОЇ ШЛЯХОМ ВИКОРИСТАННЯ ВІДВОЛІКАЮЧИХ ДЖЕРЕЛ ЕЛЕКТРОМАГНІТНОГО ВИПРОМІНЮВАННЯ
}

Найбільи ефективна протидія повітряному противнику при захисті РЛС від високоточної зброї може здійснюватися у єдиній радіолокаційній системі на основі реалізації автоматизованого адаптивного управління енергетичним та частотним ресурсом угруповання РТВ. Важсливими складовими при изьому являються розробка і приведення в дію команд по управлінню ресурсами угруповання конфліктно-стійкими методами. 3 урахуванням циих методів розглянуті роль, місие і особливості функиіонування засобів захисту РЛС від високоточної зброї у радіолокаційної системі. Розглянуті деякі вимоги до формування відволікаючих квазістаціонарних перешкод мерехтливого типу для відведення протирадіолокаційних ракет з урахуванням забезпечення необхідної інформативності РЛС і скритності ї̈ роботи.

Ключові слова: протирадіолокачійна ракета, відволікаючий пристрій, випромінювання РЛС, відволікаючі перешкоди, імовірність поразки РЛС, управління енергетичним та частотним ресурсом угруповання, конфліктно-стійкі методи управління.

\section{Вступ}

Постановка проблеми. Одним з найбільш ефективних методів протидії системі протиповітряної оборони (ППО) з боку повітряного противника $є$ вогневе ураження об’єктів ППО за допомогою високоточної зброї.

Основними напрямками боротьби з перспективними засобами високоточної зброї (у тому числі з протирадіолокаційними ракетами (ПРР) 3 комбінованими головками самонаведення) для підрозділів РТВ стає інженерне обладнання позицій, маскування радіолокаційних засобів і використання їх макетів, створення прихованого радіолокаційного поля, застосування активних і пасивних перешкод засобам розвідки і засобам наведення високоточної зброї та збільшення оманної інформації шляхом використання відволікаючих джерел електромагнітного випромінювання та перевідбиваючих пристроїв.

Збільшення оманної інформації шляхом використання засобів імітації радіолокаційного випромінювання може розглядатися як порівняно простий, але ефективний спосіб підвищення живучості РЛС, оскільки дозволяє на всіх етапах підготовки і наведення на РЛС високоточної зброї забезпечувати зниження ії ефективності.

В умовах масованого застосування протирадіолокаційних ракет на фоні перешкод і відволікаючих дій авіації дуельна боротьба з окремими засобами повітряного нападу (РЛС - ПРР) може виявитися важко здійсненною.

Тому розглядаються, стосовно оглядових РЛС РТВ, можливості формування загального поля електромагнітного випромінювання усіх відволікаючих джерел на позиції РЛС, просторові та часові характеристики випромінювання кожного з яких повинні змінюватися погоджено по єдиних командах. Завданнями управління таким полем є прикриття (маскування) випромінювання оглядових РЛС, а також формування перешкод для протирадіолокаційних ракет 3 пасивними радіолокаційними голівками самонаведення, що дозволяє знизити точність наведення на цілі засобів повітряного нападу та збиток від їх застосування.

Застосування групи відволікаючих пристроїв дозволяє забезпечити надійний захист РЛС без припинення їх роботи на випромінювання, тобто без втрати якості радіолокаційної інформації.

Аналіз останніх досліджень і публікацій. Характеристики засобів високоточної зброї, у тому числі протирадіолокаційних ракет, постійно покращуються та вдосконалюються способи їх бойового застосування.

В роботах [1-12] наведена оцінка дії вражаючих факторів ПРР на РЛС, викладена методика розрахунку імовірності ураження наземної оглядової РЛС ПРР. Актуальною проблемою є оцінка ефективності заходів захисту РЛС від ПРР та розробка способів їх застосування.

Методи захисту РЛС від протирадіолокаційних ракет можливо умовно поділити на пасивні, активні і комбіновані.

Пасивні методи застосовуються 3 метою зниження ефективності впливу протирадіолокаційних ракет шляхом удосконалення РЛС та способів їх бойового застосування. Пасивні методи полягають в підвищенні стійкості РЛС до вражаючих факторів ПРР, підвищенні енергетичної та просторової прихованості роботи та в зміні режимів роботи РЛС.

Активні методи захисту РЛС від ПРР потребують застосування додаткових засобів, які самі або у разі спільної роботи з РЛС забезпечують знищення, 
самоліквідацію або відвід ПРР на безпечну для РЛС відстань. В роботах [1-6] розглядається ефективність активних методів захисту оглядових РЛС від сучасних протирадіолокаційних ракет.

Напрямок на РЛС системою самонаведення ПРР визначається як нормаль до фазового фронту сигналу від РЛС. Застосування відволікаючих пристроїв (ВП) для захисту РЛС від ПРР веде до перекручування фазового фронту сигналу РЛС i, як наслідок, збільшення помилки наведення ПРР.

Залежність імовірності Р поразки РЛС типу 19Ж6 однією ракетою від величини середньоквадратичного відхилення (СКВ) $\sigma$ ПРР, яка розрахована по методиці [4-5], наведена на рис. 1.

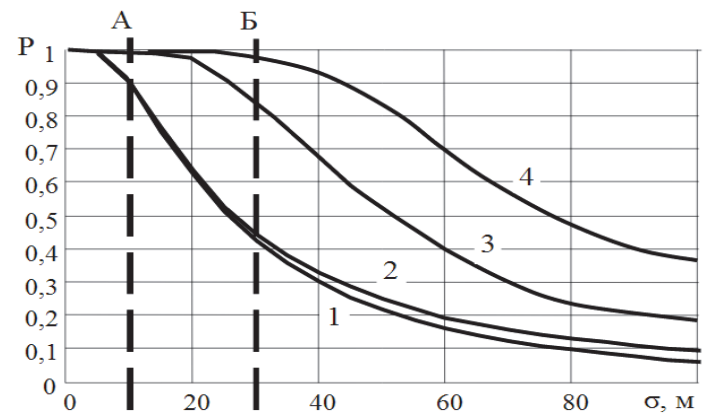

Рис. 1. Залежність імовірності ураження РЛС однією ПРР від СКВ наведення

Джерело: розроблено авторами за даними [5, С. 26].

Криві 1,2 побудовані для осколково-фугасної бойової частини ПРР з рубчастою оболонкою, криві 3, 4 побудовані для осколково-фугасної бойової частини ПРР 3 готовими вражаючими елементами. Криві 1, 3 побудовані для бойових частин масою 66 кг (ПРР HARM), криві 2, 4 відповідають масі бойової частини 20 кг (ПРР Армигер).

У випадку, коли жодних заходів щодо захисту РЛС від ПРР не вживається, система самонаведення ПРР забезпечує середньоквадратичне відхилення від РЛС до 10 метрів, відповідно імовірність ураження РЛС сягає 0,9-0,99 (область ліворуч від лінії А на рис. 1).

Якщо після виявлення ПРР випромінювання РЛС вимикається, ПРР переходить до режиму наведення з використанням інерційної системи. Цей режим забезпечує середньоквадратичне відхилення від РЛС до 30 метрів, відповідно імовірність ураження РЛС для сучасних ПРР сягає 0,8-0,9 (область ліворуч від лінії Б на рис. 1). Для ПРР з бойовою частиною рубчастого типу виключення випромінювання РЛС може знизити імовірність ії поразки до значення 0,4 .

Таким чином, застосування лише пасивних методів захисту РЛС від сучасних ПРР є неефективним.

Ефективність активних методів захисту огля- дових РЛС від ПРР з використанням ВП може бути вище. Застосування ВП може забезпечити захист РЛС за рахунок зміщення фазового центра системи відволікаючих джерел електромагнітного випромінювання.

Рівень сигналу від випромінювача-пастки повинен бути не менший сигналу, випромінюваного РЛС у напрямку на ПРР. Розрахунки показують, що для середньої потужності випромінювання РЛС (типу 19Ж6) 3 кВт, 3 рівнем бічних пелюсток 35 дБ (середній рівень), потужність ВП повинна становити не менш як 70 Вт за умови спрямованого випромінювання в напрямку дії ПРР.

На рис. 2 наведено залежність імовірності $\mathrm{P}$ ураження РЛС однією ПРР типу НАRM від зміщення $(x)$ точки наведення ПРР відносно РЛС.

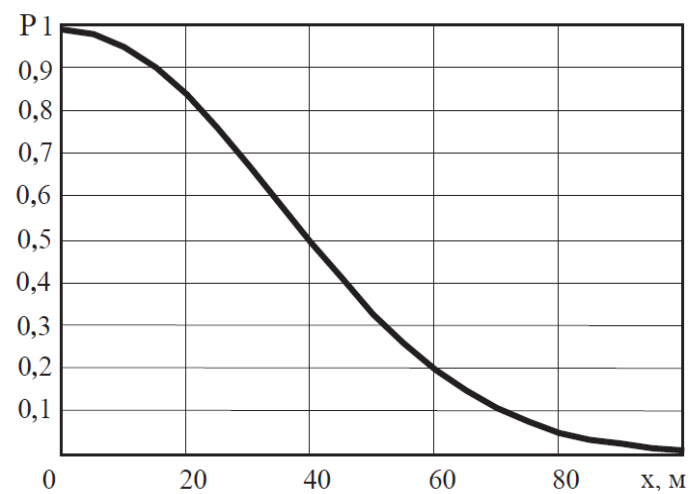

Рис. 2. Залежність імовірності ураження РЛС від зміщення точки наведення ПРР від РЛС Джерело: розроблено авторами за даними [5, С. 27].

3 графіка видно, що імовірність поразки РЛС швидко зменшується при зміщенні точки наведення від РЛС. На практиці достатньо зміщення точки наведення ПРР більш як на 100 метрів.

Очевидно, щоб зменшити імовірність поразки РЛС, ВП слід розташовувати від РЛС якомога далі, але в цьому випадку зростає імовірність іх розрізнення системою самонаведення ПРР, та з'являється можливість перенацілювання ПРР на РЛС.

Варіант застосування ВП для захисту оглядової РЛС наведено на рис. 3 [4-5].

Засіб “Газетяр-Е” (РФ) призначений для захисту РЛС від протирадіолокаційних ракет шляхом короткочасного виключення їх випромінювання по командах автономної доплерівської РЛС виявлення ПРР (праворуч на рис. 3) у поєднанні з використанням відволікаючих пристроїв в частотному діапазоні РЛС, а також створення аерозольних і дипольних перешкод системам наведення ПРР 3 тепловими, телевізійними і активними радіолокаційними голівками самонаведення. 


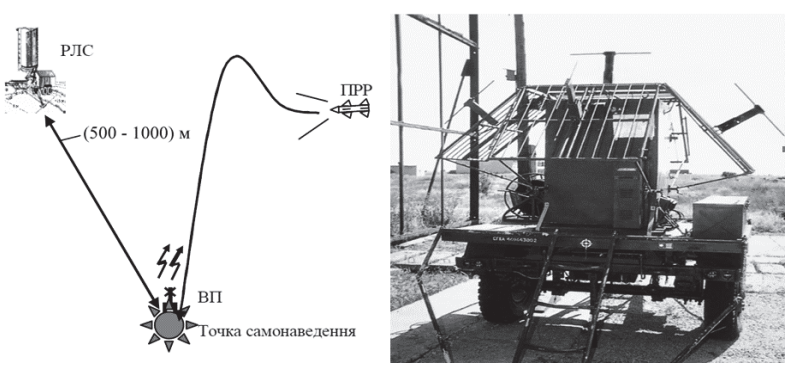

Рис. 3. Використання відволікаючого пристрою для захисту від ПРР шляхом короткочасного виключення випромінювання РЛС (засіб “Газетяр-Е”) Джерело: розроблено авторами за даними [5, С. 28].

При підльоті ПРР на відстань до 10 км робота РЛС на випромінювання припиняється та включається в роботу (продовжує працювати) ВП. Внаслідок цього точка наведення ПРР зазнає зсуву на відстань розміщення ВП від РЛС (траса польоту ПРР ліворуч на рис. 3).

Другий варіант застосування комплексної системи захисту РЛС від ПРР “Радар” (рис. 4), де також забезпечується короткочасне виключення випромінювання РЛС по командах автономної доплерівської РЛС виявлення ПРР при синхронній автоматичній роботі всіх елементів системи захисту РЛС без участі оператора. Пускові пристрої також забезпечують створення аерозольних і дипольних перешкод системам наведення ПРР з тепловими, телевізійними і активними радіолокаційними голівками самонаведення.

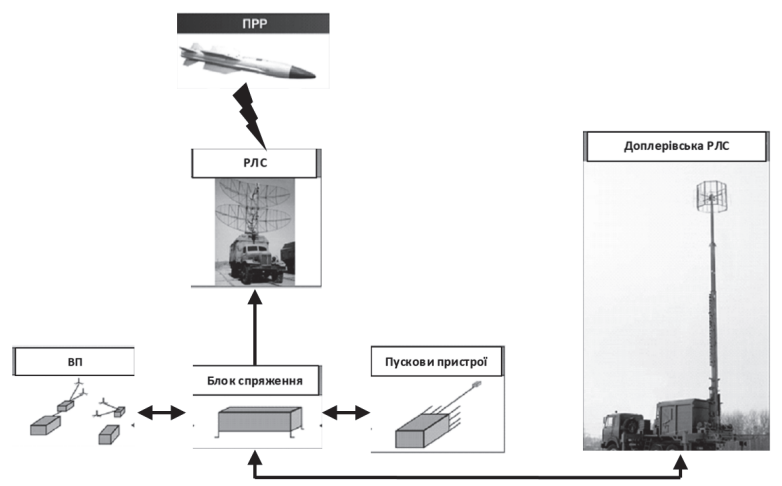

Рис. 4. Комплексна система захисту РЛС від ПРР (Республіка Білорусь, КБ "Радар")

Джерело: розроблено авторами за даними [11]

Реалізація цих варіантів можлива лише за умов надійного виявлення ПРР та потребує тимчасового (можливо, багатократного) припинення роботи РЛС, що негативно впливає на якість радіолокаційної інформації.

Збільшення числа і потужності ВП дозволяє замаскувати випромінювання РЛС і обійтися без іiі виключення. Також з'являється можливість формування відволікаючих (що відводять) мерехтливих перешкод, які знижують точність самонаведення
ПРР, особливо ракет з адаптивними антенними решітками. Для підвищення ефективності таких перешкод доцільно використати відповідні режими випромінювання РЛС.

Проте малопотужна доплерівська РЛС (метрового діапазону довжин хвиль) з широкою (ненапрямленою, півсферичною) діаграмою направленості антени не дозволяє зафіксувати напрям удару ПРР і може бути легко пригнічена активними перешкодами з будь-якого напряму. Без інформації про напрям удару формування відволікаючих перешкод для ПРР може виявитися дуже скрутним.

В умовах масованого застосування протирадіолокаційних ракет на фоні інтенсивних завад і відволікаючих дій авіації подібна дуельна автономна (у межах підрозділу РТВ) боротьба 3 окремими засобами повітряного нападу (використання засобів типу "Газетяр", "Радар" та ін.) може виявитися важко здійсненною. Тим більше, автономне управління режимами випромінювання РЛС може суперечити завданням формування єдиного радіолокаційного поля (РЛП) угруповання РТВ.

Аналіз останніх досліджень і публікацій дозволив структурувати основні методи захисту РЛС від високоточної зброї (ПРР). Актуальною проблемою залишається вибір найбільш ефективного захисту РЛС від високоточної зброї.

Мета статті - розглянути роль, місце і особливості функціонування засобів захисту РЛС від високоточної зброї у складі радіолокаційної системи угруповання РТВ при реалізації принципів автоматизованого адаптивного управління енергетичним та частотним ресурсом радіоелектронних засобів системи.

\section{Виклад основного матеріалу}

Склад, характеристики та варіанти застосування засобів імітації повинні визначатися не тільки характеристиками радіолокаційного озброєння i замислом на бойове застосування підрозділу РТВ, але і очікуваними способами протидії повітряному супротивнику у межах угруповання РТВ (ППО).

На рис. 5 наведено варіант застосування ПРР для поразки поодинокої РЛС з використанням відволікаючих і демонстративних дій авіації.

Для придушення РЛС (і доплерівського радара виявлення ПРР) використовуються (з урахуванням даних попередньої розвідки позиціі) прицільні по напрямку і частоті активні перешкоди (постановники активних перешкод - ПАП на рис. 5), що призводить до стискування зон виявлення. Імітація пуску ПРР дезорієнтує систему відбиття удару.

Удар може завдаватися групою ПРР (ударна група на рис. 5), або за допомогою ударних БПЛА, боєприпасів, що баражують в повітрі, носіїв зброї функціональної поразки і так далі. Засоби нападу, що 
завдають удару, спостерігаються з боку носових ракурсів, що додатково знижує дальність їх виявлення.

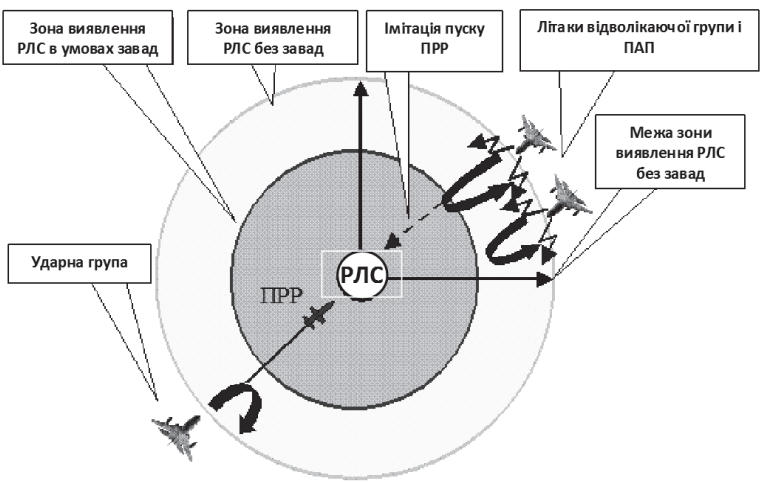

Рис. 5. Варіант застосування ПРР для поразки РЛС з використанням відволікаючих і демонстративних дій авіації

Джерело: розроблено авторами.

Перелік негативних чинників може бути продовжений. Для підвищення живучості РЛС слід використовувати інформацію РЛС флангових підрозділів угрупування, дані інших джерел, тобто доцільно переходити до організації комплексної протидії повітряному противнику у рамках усього угрупування.

Така, найбільш ефективна, протидія може здійснюватися на основі реалізації єдиного автоматизованого адаптивного управління енергетичним та частотним ресурсом угруповання РТВ (ППО), що включає наступні етапи:

- автоматичний збір, узагальнення і аналіз радіолокаційної інформації (РЛІ) від елементів бойового порядку угруповання РТВ, оцінка поточної повітряно-перешкодової обстановки і прогноз іiі розвитку;

- розрахунок просторових показників бойових можливостей угруповання у вигляді структури РЛП для різних діапазонів довжин хвиль і різних моментів часу, включаючи екстраполяцію;

- аналіз тенденцій зміни структури РЛП в часі, вироблення і приведення в дію команд з управління енергетичними і частотними ресурсами угруповання конфліктно-стійкими методами.

Послідовне виконання цих етапів в ході бойових дій (рис. 6) забезпечує безперервну адаптацію радіолокаційних засобів угруповання РТВ до поточної повітряно-перешкодової обстановки.

До даного радіочастотного ресурсу угруповання можна віднести усі засоби, що випромінюють електромагнітну енергію: РЛС (РРВ), що перебувають на озброєнні; РЛС з автоматичним дистанційним управлінням типу "Вежа"; імітатори випромінювання РЛС (відволікаючи пристрої), комплекси захисту РЛС від ПРР та ін.

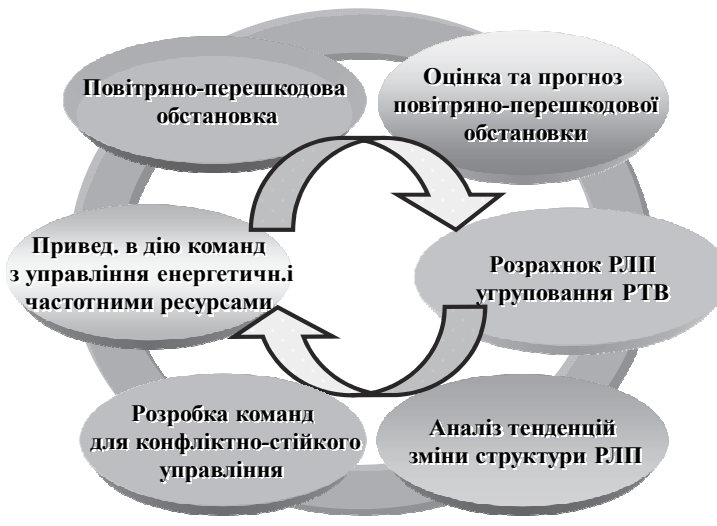

Рис. 6. Адаптивне управління енергетичними і частотними ресурсами угруповання РТВ Джерело: розроблено авторами.

РЛІ про повітряно-перешкодову обстановку та зони виявлення формується за допомогою РЛС (рис. 7-8) та засобів радіотехнічної розвідки.

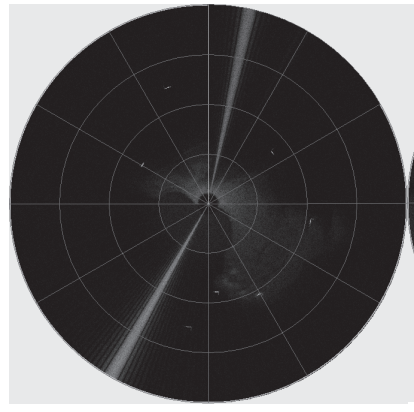

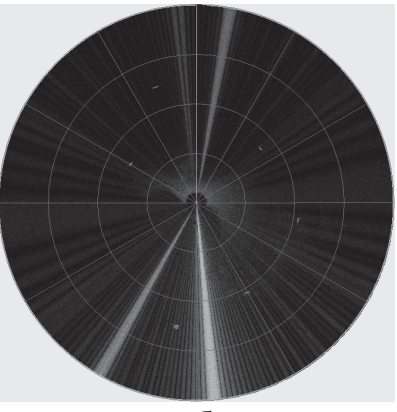

6
Рис. 7. Інформація про повітряні цілі та ПАП. Вигляд екрану ІКО РЛС 35Д6М. Діють: а - два еквівалентних ПАП 30 Вт/МГц; б - три еквівалентних ПАП 30 Вт/МГц Джерело: розроблено авторами.

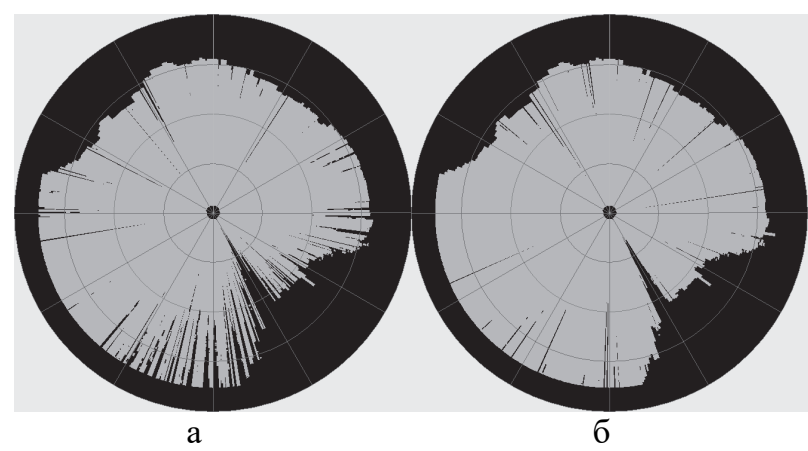

Рис. 8. Інформація про зону виявлення.

Зони виявлення цілі (1 м. кв.) РЛС 35Д6М на висоті 1000 м, один еквівалентний ПАП 15 ВТ/МГц, автокомпенсатор перешкод ввімкнено: а - режим №1; б - режим №2

Джерело: розроблено авторами.

Автоматичний збір і аналіз РЛІ від елементів бойового порядку, розрахунок РЛП (рис. 9) та аналіз тенденцій зміни його структури в часі може прово- 
диться за допомогою мережецентричної системи. В якості елементів такої системи можуть розглядатися існуюча автоматизована підсистема збору, обробки, відображення та аналізу інформації про повітряну обстановку “Віраж-планшет”, яка об'єднана 3 автоматизованої системою управління “ОреандаПС".

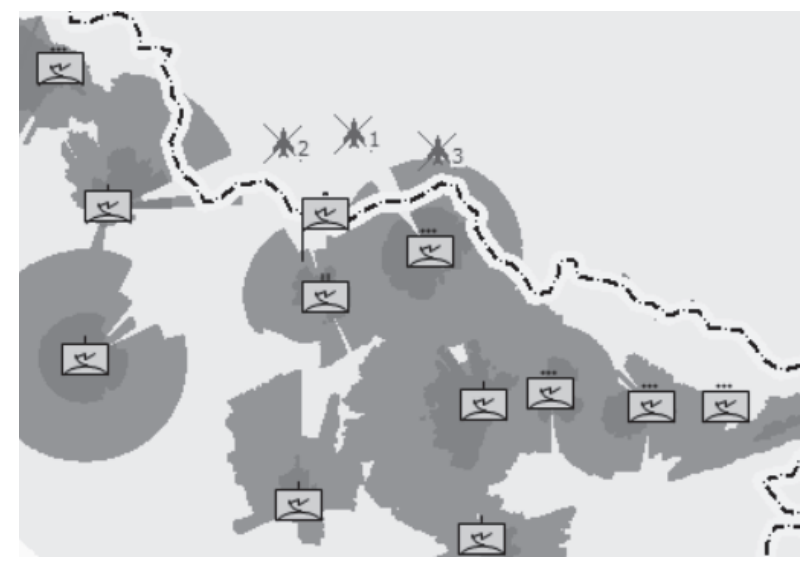

a

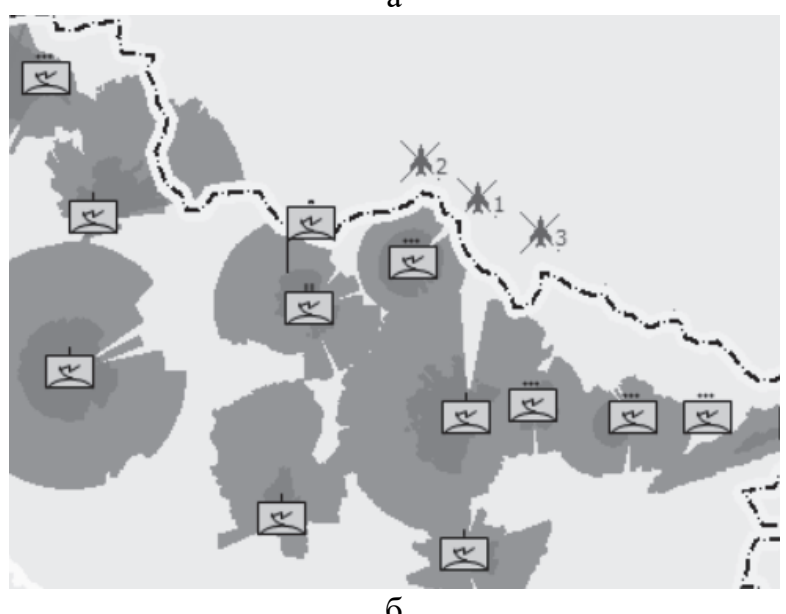

Рис. 9. РЛП угруповання РТВ (на висоті 100 та 500м для цілі типу МіГ-29) при діях ПАП на попередньому

(a) і поточному (б) кроці конфліктно-стійкого управління ресурсами радіоелектронних засобів Джерело: розроблено авторами.

Розробка і приведення в дію команд з управління енергетичними і частотними ресурсами угруповання конфліктно-стійкими методами повинні привести, зрештою, до підвищення бойових можливостей угруповання РТВ. Приведення в дію команд - це також прерогатива мережецентричної системи.

Основою методів конфліктно-стійкого управління ресурсами є розвідка повітряної та радіоелектронної обстановки й урахування реакції противника на різні режими випромінювання РЛС і інших засобів, взаємодія за вибором режимів випромінювання 3 іншими радіоелектронними засобами, прогнозування повітряно-перешкодової обстановки, використання ігрових ситуацій і формування пере- шкод для вводу супротивника в оману.

Використання методів конфліктно-стійкого управління енергетичними і частотними ресурсами угруповання можна віднести до елементів “силової" боротьби з радіоелектронними засобами противника. Розвиток цих методів пов'язаний зі створенням і вдосконалюванням мережецентричних інформаційно-керуючих систем.

Роль, місце і особливості функціонування систем захисту РЛС від високоточної зброї, з урахуванням викладеного, коротко можуть бути сформульовані таким чином.

В умовах масованого застосування супротивником високоточної зброї основною загрозою для РЛС сантиметрового і дециметрового діапазонів довжин хвиль можуть бути ПРР 3 комбінованими голівками самонаведення (ГСН). При цьому у більшості випадків головні завдання покладаються на пасивні радіолокаційні ГСН моноімпульсного типу, які мають максимальну дальність дії і можуть бути самодостатні для точного наведення ПРР.

Просторово-часова обробка сигналів на борту ГСН зводиться до накопичення пеленгаційної інформації і подальшого вагового підсумовування (згладжування) значень двомірних пеленгів при використанні кутової режекції і селекції за часом запізнювання імпульсних сигналів, що приймаються.

При використанні адаптивних антенних решіток можуть вирішуватися завдання надрозрізнення джерел випромінювання по кутових координатах. Проте процедури адаптації грунтуються на оцінках просторово-часових кореляційних залежностей сигналів (кореляційних матриць). Якість таких оцінок, особливо в умовах завадової обстановки, що динамічно міняється, може бути дуже незадовільною.

Вдосконалення захисту РЛС від даних ПРР може здійснюватися на основі використання комплексів типу “Радар" та ін. (рис. 3-4) з урахуванням ряду особливостей.

Комплекс має бути пристосовано для роботи в автономному і централізованому режимах управління і забезпечувати відведення ПРР при обмежених відомостях про напрям і час удару, типах ПРР і параметрах траєкторій їх польоту.

Такі завдання можуть бути виконані шляхом формування в заданій області простору загального поля електромагнітного випромінювання усіх джерел, просторові та часові характеристики випромінювання кожного $з$ яких повинні змінюватися погоджено по єдиних командах.

Завданнями управління таким полем є прикриття (маскування) випромінювання оглядової РЛС, а також формування квазістаціонарних відволікаючих перешкод мерехтливого типу для протирадіолокаційних ракет незалежно від їх положення в заданій області простору. Тому потужності і час 
формування випромінюваних за допомогою ВП імітуючих імпульсів мають бути керовані; бажане управління (у грубих межах) сектором випромінювання.

Для формування поля бажано притягнути РЛС, для чого використати управління ії режимами випромінювання і огляду в тих межах, які зберігають можливості успішного функціонування РЛС у складі угрупування.

До відволікаючих перешкод мерехтливого типу може бути пред'явлений ряд вимог.

Перешкоди демаскують РЛС і підрозділ РТВ, дозволяють супротивнику виявити реакцію системи ППО на його дії і витягнути з цього певні вигоди. Тому рівень додаткових випромінювань має бути, по можливості, близьким до мінімально допустимого, а характер зміни (у часі) потужності імпульсного випромінювання ВП - квазістаціонарним, близьким до характеру зміни потужності сигналів, що випромінюються РЛС у напрямі бічних пелюсток діаграми направленості іiі антени. Часові рамки початку і кінця випромінювання повинні вибиратися виходячи з аналізу усієї доступної інформації про дії противника.

Конструктивно ВП може містити перетворювач частоти і твердотілий підсилювач потужності сигналів на несучій частоті, навантажений на декілька комутованих рупорних опромінювачів зі зміщеними в просторі широкими діаграмами направленості. Імпульсні сигнали збудження, що індивідуально калібруються по амплітуді і часу затримки для кожного ВП і кожного зондуючого імпульсу РЛС, формуються на проміжній частоті в синтезаторі блоку спряження (рис. 4) і по високочастотних кабелях розподіляються по відповідних ВП. По цих же кабелях передаються команди управління ВП і напруга живлення.

Управління параметрами випромінювання ВП здійснюється виходячи з відомостей про дії повітряного противника, з урахуванням числа і конфігурації розташування ВП на місцевості, а також з урахуванням переліку допустимих для РЛС режимів випромінювання і огляду.

Помітимо, що 3 конструктивної точки зору простіше формувати відволікаючі перешкоди 3 “шумоподібним” мерехтінням, шляхом, наприклад, комутації випромінювання ВП за випадковим законом. Проте такі перешкоди сильніше демаскують РЛС. Їх можна легше розпізнати і селектирувати на борту ПРР, оскільки число можливих комбінацій взаємного розташування значень оцінок пеленгів обмежене.

До певної міри розглянуті завдання управління можуть вирішуватися на основі розробленої авторами методики оцінки ефективності різних варіантів просторового розміщення групи відволікаючих джерел та управління їх електромагнітним випромінюванням, а також випромінюванням РЛС в інтересах підвищення 价 живучості при збереженні необхідних інформаційних показників. Методика заснована на розрахунку значень показника якості, який характеризує розрізнення статистичних гіпотез або ситуацій (пов'язаних, наприклад, з радіоелектронної обстановкою).

Аналіз грунтується на розрахунку точок прицілювання ПРР (для заданих ділянок траси їх польоту) за результатами обробки на борту ракети сукупності сигналів, прийнятих від РЛС і відволікаючих пристроїв. Формування близької до оптимальної процедури обробки для пеленгації джерел випромінювання здійснюється відповідно до статистичного опису прийнятої на борту вибірки сигналів. При цьому враховуються просторові характеристики і рівні сигналів, їх взаємнокореляційні зв'язки при різних режимах випромінювання РЛС і відволікаючих пристроїв.

За результатами розрахунку точок прицілювання формується (у заданій області простору) поле помилок самонаведення ПРР (що включає середні значення помилок і параметри їх розкиду), яке характеризує ефективність прийнятого варіанту формування даних просторово-часових завад.

Подальший аналіз зводиться до розрахунку величин промахів ПРР. Для цього задається початкове положення і кут атаки ракети, після чого здійснюється кусочно-лінійна пролонгація траси їі польоту 3 урахуванням помилок самонаведення на окремих ділянках траси. Пролонгація траси здійснюється до певного рубежу, що характеризує промах ПРР відносно точок стояння РЛС і відволікаючих пристроїв. Значення промахів можуть бути перераховані (3 урахуванням типу ПРР, міри захищеності РЛС і відволікаючих пристроїв, дів. рис. 1-2) на шкоду, яка нанесена об'єкту удару. Оптимізація числа, порядку розміщення і використання додаткових джерел випромінювання для захисту РЛС може здійснюватися на основі зіставлення величини цього збитку з витратами на створення комплексу відволікаючих завад.

\section{Висновки}

В умовах масованого застосування противником високоточної зброї основною загрозою для РЛС сантиметрового і дециметрового діапазонів довжин хвиль можуть бути ПРР з комбінованими голівками самонаведення. При цьому головні завдання покладаються на пасивні радіолокаційні ГСН моноімпульсного типу, які мають максимальну дальність дії і можуть бути самодостатні для точного наведення ПРР.

Найбільш ефективна протидія повітряному противнику при захисті РЛС від високоточної зброї 
може здійснюватися у єдиній радіолокаційній системі на основі реалізації автоматизованого адаптивного управління енергетичним та частотним ресурсом угруповання РТВ.

Важливими складовими при цьому являються розробка і приведення в дію команд по управлінню ресурсами угруповання конфліктно-стійкими методами. Ці методи засновано на веденні розвідки повітряної та радіоелектронної обстановки з урахуванням реакції противника на різні режими випромінювання РЛС і інших засобів, на взаємодії при виборі режимів випромінювання з іншими радіоелектронними засобами, прогнозуванні повітряно- перешкодової обстановки, використанні ігрових ситуацій і формуванні перешкод для вводу противника в оману.

3 урахуванням цих методів розглянуті роль, місце і особливості функціонування засобів захисту РЛС від високоточної зброї у радіолокаційної системі.

Розглянуті деякі вимоги до формування відволікаючих квазістаціонарних перешкод мерехтливого типу для відведення ПРР з урахуванням забезпечення необхідної інформативності РЛС і скритності іiі роботи.

\section{Список літератури}

1. Горчица Г., Локарев Л. Боевое применение противорадиолокационных ракет класса “воздух-земля” : виртуальный авиационный справочник. URL: http://www.airwar.ru/other/article/bpprr.html (дата звернення 23.04.2021).

2. Гризо А. А., Невмержицький І. М., Купрій В. М., Пантус П. В. Аналіз стану й перспектив розвитку засобів вогневого ураження РЛС РТВ. Системи обробки інформації. 2009. № 1(75). С. 33-38.

3. Ковкін В. В., Гризо А. А. Оцінка дії вражаючих факторів протирадіолокаційних ракет на РЛС. Системи озброєння і військова техніка. 2009. № 1. С. 102-105.

4. Гризо А. А., Ковкін В. В., Невмержицький І. М. Методика розрахунку імовірності ураження наземної оглядової РЛС протирадіолокаційною ракетою. Системи озброєння і військова техніка. 2009. № 3(19). С. 14-17.

5. Гризо А. А., Ковкін В. В. Активний захист оглядових радіолокаційних станцій від протирадіолокаційних ракет. Системи обробки інформаиіï. 2009. № 6(80). С. 26-29.

6. Скорик А. Б., Камчатний М. І., Моргун Є. В., Помогаєв І. В., Іщенко Р. В., Щоголєв М. І. Аналіз особливостей побудови і застосування перспективних систем управління високоточною зброєю. Активні головки самонаведення. Системи озброєння і військова техніка. 2018. № 3(55). С. 36-43. https://doi.org/10.30748/soivt.2018.55.05.

7. Цыганок А. Применение сил и средств РЭБ в войнах и конфликтах XXI века. Независимое военное обозрение. URL: https://nvo.ng.ru/wars/2019-09-20/6_1062_reb.html (дата звернення 23.04.2021).

8. Михайлов А. Пятидневная война: итог в воздухе. Воздушно-космическая оборона. веб-сайт. URL: http://army.lv/ru/Pyatidnevnaya-voyna-itog-v-vozduhe/2566/4636 (дата звернення 22.04.2021).

9. Форский А. Средства электронной войны BMC США. Зарубежное военное обозрение. веб-сайт. URL: http://wartime.narod.ru/rlf_usa.html (дата звернення 22.04.2021).

10. Средство защиты радиолокационных станций от противорадиолокационных ракет “Газетчик-Е”. Сайт военной техники. веб-сайт. URL: http://www.rusarmy.com/pvo/pvo_vvs/reb_gazetchik-e.html (дата звернення 22.03.2021).

11. Ярош С. П., Рогуля О. В. Аналіз тактики бойового застосування крилатих ракет при нанесенні ударів по важливих державних об'єктах та угрупованнях військ. Збірник наукових праџь Харківського національного університету Повітряних Сил. 2019. № 3(61). С. 35-44. https://doi.org/10.30748/zhups.2019.61.06.

12. Шамко В. Є., Жарик О. М., Коваль В. В. Розвиток форм і способів застосування Повітряних Сил Збройних Сил України в сучасних умовах ведення збройної боротьби. Наука і техніка Повітряних Сил Збройних Сил Украӥни. 2018. № 2(31). C. 9-15. https://doi.org/10.30748/nitps.2018.31.01.

\section{Відомості про авторів:}

Трофимов Іван Миколайович

кандидат технічних наук

начальник науково-дослідного відділу

Харківського національного університету

Повітряних Сил ім. І. Кожедуба,

Харків, Україна

https://orcid.org/0000-0001-7080-909X

\section{Зюкін Володимир Федорович}

кандидат технічних наук старший науковий співробітник науковий співробітник

Харківського національного університету

Повітряних Сил ім. І. Кожедуба,

Харків, Україна

https://orcid.org/0000-0001-9461-9071

\section{Information about the authors:}

Ivan Trofymov

Candidate of Technical Sciences

Chief of Scientific Research Department

of Ivan Kozhedub Kharkiv

National Air Force University,

Kharkiv, Ukraine

https://orcid.org/0000-0001-7080-909X

\section{Volodimir Zyukin}

Candidate of Technical Sciences Senior Research

Research Associate

of Ivan Kozhedub Kharkiv

National Air Force University,

Kharkiv, Ukraine

https://orcid.org/0000-0001-9461-9071 
Гурєєв Іван Володимирович

науковий співробітник

Харківського національного університету

Повітряних Сил ім. І. Кожедуба,

Харків, Україна

https://orcid.org/0000-0002-4974-1040

Гурін Ігор Олександрович

науковий співробітник

Харківського національного університету

Повітряних Сил ім. І. Кожедуба,

Харків, Україна

https://orcid.org/0000-0002-4589-7662

\section{Дзігора Олександр Михайлович}

науковий співробітник

Харківського національного університету

Повітряних Сил ім. І. Кожедуба,

Харків, Україна

https://orcid.org/0000-0002-6614-4694
Ivan Hurieiev

Research Associate

of Ivan Kozhedub Kharkiv

National Air Force University,

Kharkiv, Ukraine

https://orcid.org/0000-0002-4974-1040

\section{Igor Hurin}

Research Associate

of Ivan Kozhedub Kharkiv

National Air Force University,

Kharkiv, Ukraine

https://orcid.org/0000-0002-4589-7662

\author{
Oleksandr Dzihora \\ Research Associate \\ of Ivan Kozhedub Kharkiv \\ National Air Force University, \\ Kharkiv, Ukraine \\ https://orcid.org/0000-0002-6614-4694
}

\title{
ЗАЩИТА РЛС ОТ ВЫСОКОТОЧНОГО ОРУЖИЯ ПУТЕМ ИСПОЛЬЗОВАНИЯ ОТВЛЕКАЮЩИХ ИСТОЧНИКОВ ЭЛЕКТРОМАГНИТНОГО ИЗЛУЧЕНИЯ
}

\author{
И.Н. Трофимов, В.Ф. Зюкин, И.В. Гуреев, И.А. Гурин, А.М. Дзигора
}

Наиболее эффективное противодействие воздушному противнику при защчите РЛС от высокоточного оружия может осуществляться в единой радиолокационной системе на основе реализачии автоматизированного адаптивного управления энергетическим и частотным ресурсом группировки РТВ. Важными составляющими при этом являются разработка и приведение в действие команд по управлению ресурсами группировки конфликтно-стойкими методами. С учетом этих методов рассмотрены роль, место и особенности функционирования средств защиты РЛС от высокоточного оружия в радиолокационной системе. Рассмотрены некоторые требования к формированию отвлекающих квазистационарных помех мериающего типа для отвода ПРР с учетом обеспечения необходимой информативности РЛС и скрытности ее работы.

Ключевые слова: противорадиолокационная ракета, отвлекающее устройство, излучение РЛС, отвлекающие помехи, вероятность поражения РЛС, управление энергетическим и частотным ресурсом группировки, конфликтностойкие методы управления.

\section{PROTECTING THE RADAR AGAINST HIGH-PRECISION WEAPONS BY USING DISTURBANT SOURCES OF ELECTROMAGNETIC RADIATION}

\author{
I. Trofymov, V. Zyukin, I. Hurieiev, I. Hurin, O. Dzihora
}

One of the most effective methods of countering the air defense system by the air enemy is the fire destruction of air defense facilities with high-precision weapons. In conditions of massive use of high-precision weapons by the enemy, the main threat to radars of centimeter and decimeter wavelength ranges may be anti-radar missiles with combined homing heads. The main tasks are assigned to passive radar homing heads of the monopulse type, which have a maximum range and can be self-sufficient for accurate guidance of anti-radar missiles. The most effective counteraction to the air enemy in the protection of radars from highprecision weapons can be carried out in a single radar system based on the implementation of automated adaptive control of energy and frequency resources of the radio-technical troops using distracting devices. The layout of the distraction devices relative to the radar allows you to adjust the radar kill probability. The use of two or more distracting devices reduces the radar kill probability without excluding them. Thus, it is possible to adjust the direction of flight of the anti-radar missile with its further diversion to the safest zone relative to the radar. Important components are the development and implementation of commands to manage the resources of the group conflict-resistant methods. These methods are based on conducting reconnaissance of the air and electronic situation, taking into account the reaction of the enemy to different modes of radiation of radar stations and other means, the interaction in choosing modes of radiation with other electronic means, forecasting airborne conditions, the use of gaming obstacles to misleading the enemy. Taking into account these methods, the role, place and features of the operation of radar protection against high-precision weapons in the radar system are considered. Taking into account the provision of the necessary informativeness of radar stations and the secrecy of its operation, some requirements for the formation of distracting quasi-stationary interferences of the flickering type for diversion of anti-radar missiles are considered.

Keywords: anti-radar missiles, distraction device, radar emitting, distracting interference, radar kill probability, management of the energy and frequency resource of the grouping, conflict-resistant management methods. 